\title{
A Handbook for Teaching English at the Secondary School
}

Praveen Kumar Yadav

\author{
Rai. V. S. (Eds.). (2013). \\ A Handbook for Teaching \\ English at the Secondary \\ School: NELTA Birgunj
}

This year Nepal witnessed the dismal results of the Iron Gate for higher studies 'School Leaving Certificate (SLC) examinations (41.57 per cent), which is five per cent lower than last year. This is the lowest percentage results in the last five years. The statistics shows that $90 \%$ out of those who fail their SLC exams, fail in core subjects such as Mathematics, English and Science. Following this gloomy situation, the Ministry of Education (MoE) concluded that the teachers are to blame for the decline in the public education sector. The ministry further has decided to announce the names of 'poor' and 'excellent' teachers in order to make school teachers more accountable. The Department of Education has directed Regional Education Directorates and the District Education Offices (DEO) to collect the names of subject teachers from schools with achievements higher and lower than the national average. It is claimed that the new initiative will motivate teachers to change their attitude and make them more accountable, arguing that those who don't want their names published will definitely perform their duties well. The government expects to increase the teachers' commitment to instruction, ultimately reversing the deteriorating quality of education in state-funded schools through this plan. However, the issue of teacher accountability is not that straightforward. Based on needs assessment, the teachers needs to be trained and supervised properly before they are made accountable.

In addition to the present scenario secondary education in Nepal as reflected above, most English teachers at secondary level lack confidence to teach poetry. They largely follow the traditional approach of teaching literature, i.e. literature is taught for literature's sake. They are not exposed to the ways how they can use poetry, 
story and other literary texts for teaching language. They complain that the training they receive for teaching particular literary items but they also need to know how such items from the textbooks can be used to help their learners develop their English language competence. The book titled A Handbook for Teaching English at the Secondary School recently published in joint effort of the contributors, led and edited by ELT veteran Prof. Dr. Vishnu $\mathrm{S}$. Rai, the principal author of grade 9 and grade 10 English textbooks, serves the dire need of English language teaching (ELT) at secondary level especially for conducting training to the secondary school English teachers. The handbook is in the form of training package designed for English teachers of secondary level taking sample lessons and texts from grade 9 and grade 10 textbooks.

The handbook consists of a training package of eight different chapters contributed by different ELT practitioners and members of English Creative Writing Group. The contributors of this handbook include Tapasi Bhattacharya, Maya Rai, Lekhnath Sharma Pathak, Motikala Subba Dewan, Balram Adhikari, Sarita Dewan, Ishwor Kumar Shrestha and Laxman Gnawali.

The first chapter, 'curriculum and textbook' helps familiarize them with the contents, methodology and evaluation of the curriculum and properly planning the units with a view to use the textbooks effectively and efficiently. It assists teachers in understanding the fact that a textbook is not to be blindly followed; its exercises and activities can be adopted, adapted and even modified or changed to suit the learners' level and interest.

The second chapter, 'literature for language development', divided into two sub-chapters 'what's literature?' and 'why teach literature?' aims to help teachers realise what literature is and why it is important to use in a language classroom to develop the learners' language skills with pleasure and fun. It finally shows the relevance in using literature in English language classrooms.

Most of English teachers in Nepal follow the traditional style of teaching poetry by introducing the poet, followed by paraphrasing the poem and concluding with a summary at the end. Few teachers know that that poems can be used effectively to help the learners develop their language skills. The need is expected to be addressed through four lessons on teaching poems included in the third chapter, 'teaching poetry'. While the two poems are 'Touch' by Hugh Lewin' and 'Where the Rainbow Ends' by Richard Rime from Grade 9 and Grade 10 textbooks respectively, two other poems are 'Harlem' by Langston Hughes and 'To Autumn' by John Keats.

Illustrating two sample stories (The Little China Chip: Grade 9 and The Golden Swan), the fourth chapter, 'Teaching Story' presents the strategies to teach stories effectively. The strategies for 
teaching story include pre-activities, while-activities and post-activities. The chapter also deals with teaching news stories with a view to enable the learners to develop news stories based on the headlines provided.

Drama helps imitate life through action and speech. Teaching drama to English learners aims to realise the effect of language and expression through drama. The secondary level English textbooks include short dramas. In the fifth chapter, 'Teaching Drama', the teachers or trainees are expected to get exposed to some of effective ways to teach drama, which they might adopt and adapt to their classroom teaching. This chapter includes three dramastwo dramas from Grade 9, Unit 10 and Grade 10, Unit 3, and one 'Importance of Being Earnest' by Oscar Wilde.

The sixth chapter entitled 'Teaching Writing' deals with different kinds of techniques which can be used to prepare the students for a writing task. It includes four sections with different strategies to motivate and facilitate students writing in ESL/EFL contexts. The first section illustrates writing an essay by using a mind map. Making a mind map is a strategy for exploring and developing ideas. Similarly, the second section presents how to describe a character using a silhouette, the third motivates for writing a postcard and the final section illustrates the ways to write a letter to a character of the story the learners have read.
The seventh chapter, 'Teaching Grammar' presents unconventional ways of teaching grammar to enable the trainees/teachers to teach grammar for communicative purposes and not for learning the grammatical rules. The grammatical items included in this chapter consist of subject-verb agreement, passive sentences and connecting your ideas as illustrative lessons. Each of them includes objectives, materials and activities followed by worksheets and grammar checklist.

The last chapter, 'Reflective Teaching and Action Research' supports the recent trend on second language teaching, i.e. a movement away from methods and other external or top down views of teaching, toward an approach often starting with the instructors themselves and the actual teaching processes by exploring what teachers do and why they do it. It mainly deals with critical selfexamination and reflection as a basis for decision making, planning and action. This chapter helps teachers get exposed to the ways and means of reflective teaching, that is, how they can be reflective teachers.

The strength of this handbook is that this manual is a complete package of training that a secondary level English teacher or trainer requires. The package deals with teaching writing, teaching grammar and teaching literature, which encompasses teaching poetry, story and drama. All the components are included in the secondary English 
curriculum. The package, most importantly, has incorporated three important aspects of teacher training viz. curriculum, textbook and reflective teaching. A teacher must know what to teach (the curriculum) with a variety of activities (the textbook) and critical self examination and reflection (reflective teaching).

This training manual brings together all the support activities and materials including handouts needed while conducting the training/workshops. The book is grounded in the realities of secondary level English teaching in Nepal and offers practical and illustrative suggestions on the sample texts from secondary level English textbooks. Thus, it further explores the contexts of ELT at secondary level contexts and comes up with handy and relevant tips and strategies to stimulate unconventional ways of teaching. The handbook begins with some suggestions on how to run teacher training, particularly using this training manual. These are salient features of this book.

\section{About the author}

Except some typos and lay-out, this book is relevant to Nepalese context, especially for conducting ELT training targeting secondary level teachers with a view to provide support for professional growth and effective teaching.

Besides teaching business communication to $B B A$ and MBA students, Mr. Praveen Kumar Yadav is the coordinator for the centre for writing and communication at King's College, Kathmandu. He is a life member of NELTA and the team coordinator for monthly blog magazine 'NeltaChoutari'. He is also one of the correspondents for the Republica, national English daily newspaper. His interests include writing, blogging, organizing discourse in various issues of ELT and community practice and also project management. 